\title{
Characteristics of HIV-1 gp120 molecules that bind ancestor, intermediate and mature forms of VRC01-like antibodies
}

\author{
M Joyce*, B Zhang, T Zhou, S Moquin, X Wu, M Louder, Z Zhang, I Georgiev, J Zhu, \\ L Shapiro, JR Mascola, GJ Nabel, PD Kwong
}

From AIDS Vaccine 2012

Boston, MA, USA. 9-12 September 2012

\section{Background}

A group of highly effective neutralizing antibodies, which target the site of CD4 binding on HIV-1 gp120, have recently been identified. These antibodies - called VRC01like antibodies - all originate from the same VH1-2*02 germline gene and, while the mature antibodies have undergone extensive maturation via non-homologous pathways, their recognition of the CD4-binding site of gp120 is similar. An efficacious vaccine that elicits VRC01-like antibodies will likely be required to bind to VH1-2*02-derived B cells to initiate their expansion and subsequent maturation, however, binding studies with reverted-ancestor VRC01-like antibodies and HIV-1 gp120 molecules typically show binding that is too weak to initiate B cell maturation.

\section{Methods}

To identify HIV-1 gp120 molecules capable of interacting with reverted-ancestor molecules with sufficient affinity to initiate B cell maturation, we screened large panels of HIV-1 pseudoviruses for sensitivity to reverted-ancestor forms of VRC01-like antibodies. Identified HIV-1 strains (and related gp120s) were then analyzed for recognition to a panel of diverse VRC01-like antibodies.

\section{Results}

No HIV-1 strains were identified which could be neutralized by reverted heavy chain- and light chain-ancestors of VRC01-like antibodies. Chimeric forms of the VRC01-like antibodies with reverted and mature heavy/ light chain mixtures did, however, neutralize a small subset of HIV-1 isolates. Characterization of gp120s

Vaccine Research Center, NIAID/NIH, Bethesda, MD, USA from the sensitive subset found measurable affinity to the ancestral forms of VRC01-like antibodies. In comparison, typical gp120 molecules, e.g. YU2 gp120, fail to bind low-divergent forms of the VRC01-like antibodies, i.e. those with less than $10 \%$ divergence from germline.

\section{Conclusion}

Select strains of HIV-1 can interact with ancestral forms of VRC01-like antibodies. Defining the specific characteristics of these select strains should enable identification of gp120-derived immunogens capable of productive interactions with $\mathrm{VH} 1-2 * 02$-derived B cells.

Published: 13 September 2012

doi:10.1186/1742-4690-9-S2-P68

Cite this article as: Joyce et al:: Characteristics of HIV-1 gp120 molecules that bind ancestor, intermediate and mature forms of VRC01-like antibodies. Retrovirology 2012 9(Suppl 2):P68.

Submit your next manuscript to BioMed Central and take full advantage of:

- Convenient online submission

- Thorough peer review

- No space constraints or color figure charges

- Immediate publication on acceptance

- Inclusion in PubMed, CAS, Scopus and Google Scholar

- Research which is freely available for redistribution 